January 2017

\title{
Data Services in Academic Libraries - What Strange Beast Is This?
}

Amanda J. Swygart-Hobaugh M.L.S., Ph.D.

Georgia State University, aswygarthobaugh@gsu.edu

Follow this and additional works at: https://scholarworks.sjsu.edu/ischoolsrj

Part of the Scholarly Communication Commons

\section{Recommended Citation}

Swygart-Hobaugh, A. J. (2017). Data Services in Academic Libraries - What Strange Beast Is This?. School of Information Student Research Journal, 6(2). https://doi.org/10.31979/2575-2499.060202 Retrieved from https://scholarworks.sjsu.edu/ischoolsrj/vol6/iss2/2

This article is brought to you by the open access Journals at SJSU ScholarWorks. It has been accepted for inclusion in School of Information Student Research Journal by an authorized administrator of SJSU ScholarWorks. For more information, please contact scholarworks@sjsu.edu. 


\title{
Data Services in Academic Libraries - What Strange Beast Is This?
}

\begin{abstract}
Data services, though a longstanding specialization, is a fast-growing and in-demand niche in the academic librarian job market. That said, it is still somewhat of a mystery to many outside of a small circle in academic librarianship. This essay attempts to remedy this mystification. The author gives an overview of data services librarianship, using examples from her San José State University INFO 220-12 class, "Data Services in Libraries," to illustrate the core aspects and activities of this specialization in academic libraries. In so doing, she elucidates how this specialization is at once a natural extension of established roles for academic librarians and also an opportunity for librarians to expand their roles for increased relevancy in the higher education research enterprise.
\end{abstract}

\section{Keywords}

data services, academic librarianship, LIS education

\section{About Author}

Mandy Swygart-Hobaugh is the Team Leader for Research Data Services as well as the Librarian for Sociology, Gerontology, and Data Services at the Georgia State University Library. She is also the sole campus-wide trainer for NVivo qualitative data analysis software and chairs the Data Management Advisory Team. In addition to her MLS from Indiana University, she has a MS and PhD in Sociology from Purdue University. She has taught INFO 220-12 Data Services in Libraries at San José State University since Fall 2014. 
As an academic librarian, explaining my job to the average person on the street is not easy. As soon as they hear "librarian," most people immediately conjure up the image of a public librarian who leads children's story hour, gives them advice on what book they should read next, or helps them find that obscure tax form. I then further compound their confusion by telling them I am a "data services" librarian. Nowadays the moment people hear the word "data," they most likely think of their smartphone's data plan, and then they think, "Why do we need a librarian for THAT?" Even within the academic world, most students and faculty, when told someone is a "data services" librarian, will furrow their brows in puzzlement. And due to its relative rarity as a specialization, many academic librarians themselves find the notion of "data services" perplexing. As a practicing data services librarian I myself am often unsure about what I am or should be doing - and I betray this uncertainty by compulsively putting air quotes around the phrase "data services" when telling people my job title.

Thus, this essay is a brief but sweeping attempt to demystify what is this strange beast called data services in academic libraries. Since the best way to elucidate something abstract is to give concrete examples, I will describe activities from my San José State University INFO 220-12 class, "Data Services in Libraries," which illustrate the core aspects of this specialization in academic libraries. In so doing, I hope to elucidate how this area in academic libraries is simultaneously scary and exciting - as it often sends us fumbling out of our comfort zones but challenges us to flex our intellectual curiosity, deepen our knowledge, and expand our roles, which is what librarianship is all about.

\section{What's "Data," and What "Services" do Data Services Librarians Provide?}

Kellam and Thompson (2016, p. 3) offer a broad definition of what researchers and data services professionals supporting them generally envision as "data":

The data we are concerned with here are the product of taking that raw informational input and assembling it into a structured form for analysis. Data are a product of research as well as an input for research. Research data collections (or datasets) are generally in electronic form and are accompanied by or incorporate metadata, or documentation that describes the structure and content of the data. In brief...data will be taken to mean electronic files containing information that has been collected systematically, structured, and documented to serve as input for further research. Data are the raw materials for research, produced through any systematic collection of information for the purpose of analysis.

From this definition, data can be both numeric/quantitative (e.g., an SPSS statistical software file containing data collected from the General Social Survey, an annual U.S. national-level sample study of attitudes toward various social issues) or qualitative (e.g. recordings or textual transcriptions of in-depth interviews with a smaller sample of adults asking them open-ended questions about their attitudes). As Kellam and Thompson (2016) note, most raw data cannot be found, understood, or reused by others unless it is accompanied by metadata or documentation. For example, the SPSS file containing the raw, numeric data from the General Social Survey would be accompanied by a PDF or TXT "codebook" file that contains the 
purpose of the study, the data collection and sampling methods, the wording of the questions asked, and the response choices accompanied by the numeric value or code corresponding with that response choice in the SPSS file (e.g., Yes $=1$, No = 2, Don't Know = 9, No Answer = 99).

Academic librarians are accustomed to collecting, cataloging, and helping users find and use the scholarly publications produced from researchers' analysis of data. A "databrarian," to borrow Kellam and Thompson's (2016) portmanteau, essentially fulfills these same purposes, except their focus is on collecting, cataloging, and helping others find and use the raw data on which these scholarly publications were based. So, in many ways data services is a natural extension of the established roles of academic librarians. Likewise, it can encompass all the various specializations of librarianship: collection development and management, cataloging and metadata creation, and reference and instruction. In addition to these typical areas of support, some data services librarians are venturing into more unchartered waters by providing training and support for statistical analysis softwares (e.g., SPSS, SAS, Stata, R), for qualitative analysis softwares (e.g., NVivo, Atlas.ti, Dedoose), and for cleaning, organizing, and formatting data files for analysis purposes and long-term access and preservation. Likewise, data visualization services (e.g., GIS mapping, social networking visualizations) are frequently housed in academic libraries and offered by librarians. Finally, data services librarians are increasingly supporting researchers' management of their data throughout the entire research data lifecycle. For a comprehensive look at the levels, variety, and possibilities of data services within academic libraries, I would strongly encourage reading the following texts:

Kellam, L. M., \& Thompson, K. (Eds.). (2016). Databrarianship: The academic data librarian in theory and practice. Chicago: Association of College and Research Libraries.

\section{Kellam, L. M., \& Peter, K. (2011). Numeric data services and sources for the general reference librarian. Oxford: Chandos Publishing.}

Geraci, D., Humphrey, C., \& Jacobs, J. (2012). Data basics: An introductory text. Ann Arbor, MI: Inter-University Consortium for Political and Social Research. Retrieved from http://3stages.org/class/2012/pdf/data_basics_2012.pdf

\section{What Background Does a Data Services Librarian Need?}

I teach INFO 220-12 Data Services in Libraries at San José State University, and in this course I touch on the knowledge, experience, training, and skills one would need to be a successful data services librarian, in my professional opinion. And, because my own experience primarily lies in the public services and social sciences realm, the course was constructed to give students a taste of what public-services, social-sciences data services librarians do in their day-to-day. As such, the course assignments are very real-world/application oriented and, at times, a bit of a baptism by fire - reflecting my experience that much of librarianship in general and data services librarianship in particular is a learn-by-doing-and-sometimesmessing-up experience. 
One of the best ways to gauge what knowledge, experience, training, and skills are necessary for a specific career path is to look at job postings in that area. Thus, students start my course by reading Xia and Wang's (2014) article that examines the core competencies and responsibilities in data services librarian job postings. My students also look at some current data-services job postings to gauge for themselves their readiness for such positions and what knowledge, skills, etc., they believe they would need to build to get that position. In my first lecture I cite highlights from Xia and Wang's (2014) findings to contextualize what we will be covering in the course and how it maps back to actual data services librarian job expectations.

Perhaps the most pressing question besetting data services librarianship is this: Does a librarian need a data/statistical and research methodologies background to adequately offer data services? As with any subject specialization within academic librarianship, I think the honest answer is that, yes, if you have such a background you are going to have an edge in supporting data users as compared to someone who does not. However, I also think that with study and perseverance one can gain enough foundational knowledge and disciplinary language in these areas to adequately support data users without having to have an undergraduate degree, second masters, or Ph.D. in a data-heavy discipline. Thus, I have a unit dedicated to students' learning key statistical and data literacy concepts, and all the remaining course units and assignments require their application.

The next course unit is focused on data reference and instruction models and approaches, as a core responsibility of public-service-oriented data services librarians is teaching data users how to find, evaluate, and use data and statistics in their project. In this unit students are first exposed to Geraci, Humphrey, and Jacobs" (2012) "levels of reference" service that will serve as a foundational framework for approaching their remaining course assignments. Geraci et al. (2012) demarcate these levels to compartmentalize data reference into a hierarchy of basic to advanced data reference/instruction; in addition, they believe that the level structure can assist data services providers in clearly articulating what services they will and will not provide. Throughout the course, we discuss how neat and nice these levels and "we'll do this but not that" service plans look on paper, but how in practice a data services librarian is often negotiating these boundaries on the fly. Similarly, we have sometimes passionate discussions of who on campus should hold responsibility for some levels and kinds of data services - e.g., should librarians be teaching students statistical and data literacy concepts and how to use statistical software, or should that only fall in the realm of faculty's responsibilities? Through these discussions students learn that, much like all library positions, data services librarians are in a constant state of figuring out their roles and responsibilities - and, while intimidating and sometimes frustrating, it is the flexibility and constant opportunity for growth that also makes the position stimulating and fun.

After laying this foundation for going forward, we spend four weeks exploring various resources for identifying ready-made statistics, datasets ready for crunching, raw data resources for generating statistics online and extracting datasets for analysis in statistical softwares (with a demo of SPSS to give them a 
basic feel for getting data users started in its environment), and qualitative data (with a demo of NVivo qualitative data analysis software). We have another unit dedicated to discussing researchers' data management needs across the research data lifecycle - once again problematizing where librarians seem to fit in that cycle and where we might be perceived as overstepping our bounds. And we have a last unit dedicated to assessing data users' needs, developing a data service plan in response to those needs, and marketing those data services to targeted users.

When it comes to the course assignments, I basically plunge the students into the data-services deep end and hope they can swim - much like my experience when I first took on data services responsibilities in my own career. The assignments simulate very real-world, practical scenarios that one would experience as a data services librarian:

- Engage in a data reference email exchange with Mandy the Graduate Student, a first-year master's student seeking help in finding a dataset for her thesis research.

- Develop an instruction plan for a social sciences data or statistical resource and/or data or statistical literacy concept and deliver that instruction via a recorded presentation or a Guide on the Side tutorial.

- Conduct an environmental scan of the data services needs of a social sciences department, create a service plan in response to those needs, and craft a marketing plan for those services.

- Engage in an email exchange with Mandy the Faculty Researcher who is asking for assistance with writing a Data Management Plan (DMP) for her research project grant that must meet the National Science Foundation Directorate for Social, Behavioral, \& Economic Sciences (NSF-SBE) guidelines.

Through these assignments, students get to exercise the knowledge and skills they learned in the course. Also, they get firsthand experience of what actual data services librarians do in their day-to-day work - including the uncertainty, constant role and boundary negotiation, and baptism-by-fire experiences that they face in the line of duty.

\section{The First Step to Taming the Beast is Naming It}

To conclude, data services librarianship is a longstanding yet fast evolving field. And at times it can feel a bit unwieldy and may not be for the light of heart. But, as facing uncertainty with curiosity, tenacity, and aplomb is the nature of this beast called librarianship, perhaps data services isn't such a strange beast after all.

\section{References}

Geraci, D., Humphrey, C., \& Jacobs, J. (2012). Data basics: An introductory text. Ann Arbor, MI: Inter-University Consortium for Political and Social Research. Retrieved from http://3stages.org/class/2012/pdf/data_basics_2012.pdf

Kellam, L. M., \& Thompson, K. (Eds.). (2016). Databrarianship: The academic data librarian in theory and practice. Chicago: Association of College and Research Libraries. 
Swygart-Hobaugh: Data Services in Academic Libraries - What Strange Beast Is This?

Xia, J., \& Wang, M. (2014). Competencies and Responsibilities of Social Science Data Librarians: An Analysis of Job Descriptions. College \& Research Libraries, 75(3), 362-388. 